Scripta Neophilologica Posnaniensia. Tom XIII, strony: 167-184

Wydział Neofilologii, Uniwersytet im. Adama Mickiewicza w Poznaniu, 2013 DOI 10.7169/snp.2013.13.14

\title{
PRZYRODA W OCZACH POETÓW MODERNIZMU - MORZE PORANNE KONSTANDINOSA KAWAFISA I ZMIERZCH MISTYCZNEGO WIECZORA PAULA VERLAINE'A
}

\author{
DOMINIKA GLIŃSKA
}

Założenia modernizmu zrewolucjonizowały wiele poglądów funkcjonujących w dotychczasowej poezji. Stało się to głównie za sprawą sylwetki Charlesa Baudelaire'a, którą należy scharakteryzować jako kluczową dla tego przełomu. Zarówno środki jego poetyckiego wyrazu, jak i tematyka oraz teorie na temat roli i funkcjonowania literatury wywołały burzę wśród środowisk literackich w całej Europie $^{1}$. Jego spojrzenie na sztukę było, jak na tamte czasy, szokująco nowatorskie. W kulturze, w której do tej pory prym wiódł romantyzm, założenia takie jak bezosobowa forma wiersza, zmysłowa cielesność, czy liczne prozaizmy stanowiły elementy burzące cały światopogląd na literaturę. Szybko jednak początkowe zaszokowanie zastąpił głęboki podziw dla postaci Baudelaire’a. Coraz

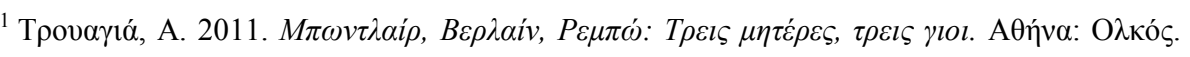
$58-76$.

Kwiaty zła zostały wydane 25 czerwca 1857. Już 5 lipca nadeszła fala pełnych cynizmu i ironii krytyk, zapoczątkowanych artykułem w Le Figaro autorstwa G. Bourdona. 14 lipca w czasopiśmie Le Moniteur ukazał się pełen zachwytu artykuł E. Thierry'ego, niemniej nie był on w stanie zmienić opinii paryskiego literackiego świata na temat tomiku Baudelaire'a. W tym samym miesiącu autorowi wytoczono proces o „oburzenie moralności publicznej” i „obrazę moralności religijnej”. W wyniku procesu Baudelaire oraz jego wydawca zostali skazani na karę grzywny, a na tomik została nałożona cenzura.
} 
więcej młodych twórców ${ }^{2}$ zachwycało się jego poezją i szukało w niej inspiracji dla własnych dzieł. Poeci rozumieli, że nadszedł czas na wykształcenie nowego, rewolucyjnego, modernistycznego wyrazu. Koniec XIX wieku zaowocował wielością prądów, takich jak na przykład impresjonizm, dekadentyzm, symbolizm, estetyzm, ekspresjonizm czy futuryzm, w których twórcy dowolnie poszukiwali odpowiednich dla siebie założeń. Podstawowym celem było jednak sięgnięcie do technik i motywów niestosowanych w poezji lub też wykorzystanie tych dotychczasowych w zupełnie odwrotny, nowatorski sposób. To założenie bardzo wyraźnie widać na przykładzie modernistycznego podejścia do obrazów natury. Powszechnie mówi się, że przyroda jest całkowicie nieobecna u wczesnych poetów europejskiego modernizmu, zachwyconych krajobrazem miasta i wszelkim sztucznym, stworzonym przez człowieka pięknem ${ }^{3}$. Nie każdy modernista ograniczał się jednak tylko do inspiracji czerpanych z rodzącego się futuryzmu. Natura istnieje w poezji modernistów, niemniej pełni tam specyficzną rolę, co chciałabym pokazać na przykładzie dwóch utworów zaczerpniętych z różnych kręgów kulturowych - Morza porannego Konstandinosa Kawafisa oraz Zmierzchu mistycznego wieczora Paula Verlaine'a.

Obydwaj poeci, choć przejawiający w swojej twórczości pewne analogie, nie są ze sobą w żaden sposób związani. Jednak analizując dorobek poetycki obydwu twórców, pomimo różnych środków wyrazu, niewątpliwie widać podobne tendencje i analogiczne cele. Przy pierwszej próbie zgłębienia ich sylwetek odnalezienie pewnych wspólnych cech może wydać się absurdalne. Ich drogi poetyckie zupełnie się mijają. Poeta przeklęty, Paul Verlaine, jako silnie zainspirowany impresjonizmem prekursor francuskiego symbolizmu, tworzył w Paryżu oraz podczas podróży do Anglii i Belgii w II połowie XIX wieku ${ }^{4}$. Natomiast twórczość Konstandinosa Kawafisa, poety nowogreckiego mieszkającego wśród greckiej diaspory w egipskiej Aleksandrii na przełomie XIX i XX wieku ${ }^{5}$, charak-

\footnotetext{
${ }^{2}$ Przede wszystkim nowo kształtujący się symboliści P. Verlaine, A. Rimabaud, S. Mallarme.

${ }^{3}$ Przyspieszona urbanizacja i industrializacja społeczeństw europejskich przyczyniła się także do zmian w literaturze końca XIX i początków XX wieku, które zaowocowały przeniesieniem zainteresowania twórców z potęgi sił natury na potęgę sił ludzkiej cywilizacji. Skrajnie widać tę tendencję w założeniach np.: futuryzmu z F. T. Marinettim na czele.

${ }^{4}$ D' Eaubonne, F. 1963. Niepokój życie Verlaine'a. Warszawa: Czytelnik. 36. W 1872 roku stosunki między Verlaine'em i jego żoną stają się nie do wytrzymania. Poeta decyduje się na ucieczkę w towarzystwie Rimbauda. Artyści wyruszają najpierw do Belgii, a następnie, po trzech tygodniach włóczenia się po Brukseli podejmują decyzję o wyjeździe do Londynu. Tam dochodzi do sprzeczki, w wyniku której Verlaine zostawia Rimbauda i sam wyrusza z powrotem do Brukseli. Zrozpaczony Rimbaud rusza za nim. W Brukseli jednak sytuacja między nimi jest bardzo napięta. Podczas burzliwej kłótni w lipcu 1873 roku Verlaine strzela do Rimbauda, co kończy się skazaniem go na karę więzienia.

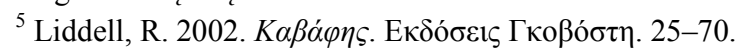


teryzowała się ironią i głębokim realizmem. Niemniej, porównując całościowy przekaz ich nowatorskich poetyk, wyraźnie widać, że obydwoje dążyli do stworzenia i wcielenia w swoje dzieła pewnego osobistego, modernistycznego ducha, silnie nasyconego antropocentryzmem i prostotą wyrazu. Dla współczesnej poetyki te wyznaczniki są na tyle powszechne, że nie mogłyby zostać uznane za podstawę do wysnuwania tez o podobieństwie w twórczości dwóch poetów. Jednak na przełomie XIX i XX wieku stanowiły one o nowatorstwie i zwrocie w stronę przełomu, który ukształtował charakter obecnych poetyk. O pewnej równoległości ${ }^{6}$ pomiędzy Kawafisem a Verlainem możemy mówić nie tylko ze względu na sprzeciw wobec dotychczas wyznawanych kanonów oraz zwrot ku nieosobowej poezji. Niejednokrotnie inspirowała ich podobna tematyka, szczególnie związana z przemijaniem i na zawsze utraconą przeszłością. Nie powinien zatem dziwić fakt, że liczne utwory zarówno jednego jak i drugiego poety są poświęcone wspomnieniom i powstającym pod ich wpływem fantastycznym wizjom. W wybranych przeze mnie wierszach, obrazy natury zostały wplecione właśnie $\mathrm{w}$ te, zainspirowane wspomnieniami wyobrażenia. Zatem pejzaż nie jest bodźcem do realistycznego opisu, czy też impresjonistycznego odmalowania, nie funkcjonuje także jako centrum utworów. Możemy go uznać jako element składowy, tworzący obraz ludzkiego wnętrza. W obydwu przypadkach zostaje ukazany poprzez subiektywną wizję podmiotu lirycznego. Najważniejszy w sytuacji lirycznej pozostaje człowiek, który łącząc w swojej wyobraźni piękno widzianego krajobrazu, zacierające się wspomnienia i wytwory własnej fantazji, tworzy niepowtarzalne wrażenie, swoisty sen na jawie. Bodźcem do powstania tych wizji jest właśnie natura, a przede wszystkim jej światło.

W Morzu porannym (1915) Kawafisa wyobraźnię podmiotu lirycznego pobudzają promienie wschodzącego słońca. Spróbujmy stworzyć scenariusz, który mógłby doprowadzić nas do przedstawionej sytuacji lirycznej: człowiek podczas przechadzki o poranku dociera do miejsca, z którego może obserwować grę światła na rozpościerającym się przed nim morzu, zlewającym się w jedność $\mathrm{z}$ błękitnym niebem. Oddajmy teraz głos samemu podmiotowi:

Kawafis także odbył kilka podróży, niemniej zdecydowanie mniej burzliwych. Dzieciństwo spędził w Londynie, po czym przez pewnien okres przebywał w Konstatynopolu u swojego dziadka. W dorosłym życiu ograniczył się do krótkich wyjazdów do stoli Europy: Paryża, Londynu, no i oczywiście Aten.

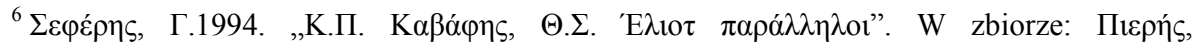

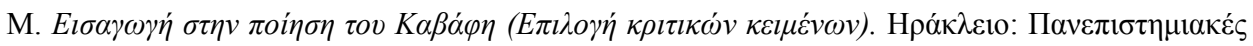

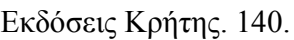

Celowo używam terminu równoległość nawiązując tym samym do artykułu G. Seferisa z zakresu krytyki porównawczej pomiędzy sylwetkami Kawafisa i Elliota. Idę tropem greckiego poety i krytyka, twierdząc, że pewne analogie pomiędzy poetyckimi sylwetkami mogą istnieć niezależnie od braku obopólnych wpływów między autorami. 


\section{Morze poranne}

Tu stanąć chcę. Niech i ja trochę popatrzę na przyrodę. Morza porannego i bezchmurnego nieba świetliste lazury - i żółte wybrzeże. Wszystko piękne i ogromne w tym świetle.

Tu stanąć chcę. I niech się łudzę, że to oglądam (to, co przez chwilę po przyjściu naprawdę widziałem), a nie - nawet tu - moje wyobrażenia, wspomnienia, widma miłosne. ${ }^{7}$

Podmiot liryczny stoi zatem nad brzegiem morza i podziwia zapierającą dech w piersiach przyrodę, oświetloną blaskiem wschodzącego słońca. Jednak po opisie bezchmurnego nieba, świetlistych lazurów i żóltego wybrzeża zaskakuje nagły zwrot w tematyce wiersza. Ani tytuł, ani pierwsza strofa w niczym nie zapowiadają nadchodzącej zmiany. Czytając utwór jesteśmy przekonani, że to tytułowe morze poranne jest jego tematycznym centrum. Przecież to właśnie ono zostało wyróżnione w tytule. Utwierdza nas w tym również opis piękna obserwowanego krajobrazu. Chciałabym zwrócić uwagę na liczne, jak na twórczość Kawafisa, przymiotniki ${ }^{8}$. Z reguły tę część mowy ciężko odnaleźć w jego dziele, natomiast $\mathrm{w}$ tym przypadku każdy wymieniany element pejzażu został określony za pomocą przymiotnika. Nie mamy wątpliwości, że podmiot ulega czarowi rozpościerającego się przed nim widoku, skoro twierdzi, że wszystko piękne i ogromne w tym świetle. Zwróćmy także uwagę na pierwsze zdanie wiersza: Tu stanąc chcę. Coś musiało przykuć uwagę osoby mówiącej, skoro zdecydowała się zatrzymać właśnie w tym miejscu. Może stąd widać cały bezkres morza? A może najdłuższe pasmo wybrzeża? Zagadkowo brzmi jedynie postanowienie Niech $i$ ja trochę popatrze na przyrodę. Czyżby podmiot nie był miłośnikiem krajobrazów i nagle przekonał się, że natura potrafi być ucieleśnieniem piękna? Już chciałoby się powiedzieć, że wbrew przekonaniom krytyków Kawafis jednak zamieścił w swoim dziele utwór poświęcony naturze ${ }^{9}$.

\footnotetext{
${ }^{7}$ Kawafis, K. 1981. Morze poranne. W zbiorze: Kawafis, K. Wiersze zebrane. Przekład Zygmunta Kubiaka. Warszawa: Państwowy Instytut Wydawniczy. 110.

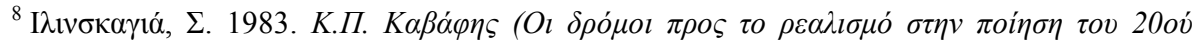

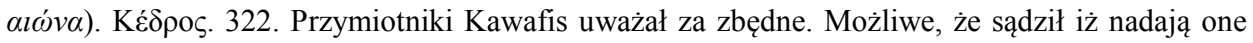
wyrażeniom zbyt subiektywny, a przez to za mało bezosobowy charakter. Niemniej główną rolę wyrazu przejmuje w jego poezji czasownik. Natomiast zamiast wyszukanych metafor, epitetów i porównań w jego wierszach czytelnik napotyka intrygującą grę interpunkcji i powtórzeń.

${ }^{9}$ Kawafis bardzo skrupulatnie kontrolował swoje wiersze. Po roku 1903, kiedy dokonał swoistej cenzury, dopuszczał tylko niektóre wiersze do tzw. kanonu. W efekcie kanon wierszy uznanych przez samego poetę za nadające się do druku liczy 154 wiersze. Pisząc o tym, że zamieścił w swoim dziele utwór poświęcony naturze mam na myśli właśnie ten kanon. Wśród wszystkich
} 
Jednak przechodząc do lektury kolejnej strofy, zaczynamy rozumieć, że celem utworu nie jest opiewanie przyrody porannego morza. Piękno morskiego krajobrazu staje się jedynie urealistyczniającym tłem dla wewnętrznych przeżyć podmiotu. Początkowo wprowadza nas $\mathrm{w}$ błąd powtórzenie stwierdzenia Tu stanać chcę. Wydaje się, że to podziw nad zapierającym dech $\mathrm{w}$ piersiach widokiem jest powodem tego pragnienia. Nie następuje po nim jednak wypełnienie postanowienia pierwszej strofy, bowiem tak naprawdę podmiotowi nie udało się trochę popatrzyć na przyrodę. Okazuje się, że piękno oświetlonego porannym blaskiem morza widział tylko w chwili, gdy stanął nad jego brzegiem. Co więc zaprzątnęło jego umysł w takiej scenerii? Nawet tam, widzi on tylko wytwory swojej 'hedonistycznej' ${ }^{10}$ fantazji, swoje wyobrażenia, wspomnienia, widma miłosne, które przysłaniają mu cały świat, otaczają go i żyją wokół niego. Warto zwrócić uwagę na oryginalny grecki tekst ${ }^{11}$, w którym poeta określa swoje wizje jako $\imath v \delta \alpha ́ \lambda \mu \alpha \tau \alpha \tau \eta \varsigma \eta \delta o v \eta ́ \varsigma$, które Z. Kubiak przetłumaczył jako widma miłosne. To określenie jest oczywiście jak najbardziej ekwiwalentne, gdyż w języku polskim nie występuje dokładny odpowiednik greckiego słowa $\eta \delta o v \eta ́$. Wyraz występuje w erotykach Kawafisa bardzo często i jest dla nich niezwykle ważny, więc uważam, że jego znaczenie powinno zostać nieco szerzej opisane. Według słownika języka nowogreckiego autorstwa G. Babiniotisa $\eta \delta o v \eta ́$ to uczucie przyjemności związanej z zaspokojeniem biologicznych pragnień i potrzeb człowieka, które dotyczy przede wszystkim czerpania intensywnej przyjemności cielesnej ${ }^{12}$. Zatem należy mieć świadomość, że owe wymienione w wierszu widma miłosne są związane ze słodką przyjemnością, płynącą z zaspokojenia cielesnych pragnień. Godne zainteresowania jest także filologiczne znaczenie drugiego, użytego w tym środku stylistycznym wyrazu. Mam na myśli

wierszy Kawafisa znajduje się kilka, w których widoczny jest motyw natury, niemniej w kanonie krajobraz występuje tylko w Morzu porannym.

${ }^{10}$ Celowo używam stwierdzenia hedonistycznej fantazji, nawiązując tym samych do środka stylistycznego użytego w oryginale wiersza. Hedonizm to zapożyczenie ze starożytnej greki,

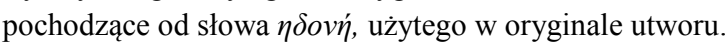

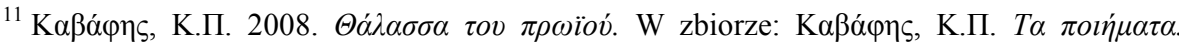

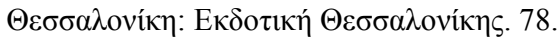

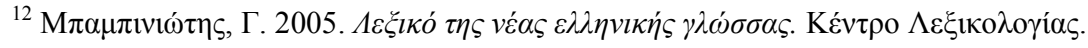

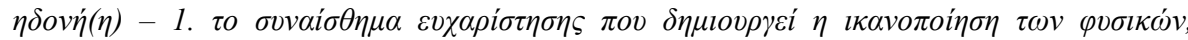

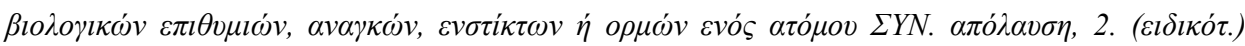

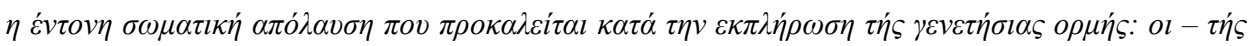

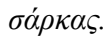

Abramowiczówna, Z. 1960. Stownik grecko - polski. Tom II. Warszawa: PWN.

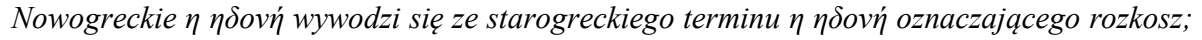
$\eta \eta \delta o v \dot{~-~ 1 . ~ r o z k o s z, ~ p r z y j e m n o s ́ c ́, ~ u c i e c h a ~ z m y s ł o w a, ~ w ~ p o ł a c z e n i u ~ \tau o v ~ \sigma \omega ́ \mu \alpha \tau o \varsigma, ~ a ~ z a t e m ~ c i e l e-~}$ sna; 2. przedmiot radości; 3. pl. pragnienia, żądze. 
wyraz $i v \delta \alpha \lambda \mu \alpha$, który w języku greckim posiada dwa znaczenia. Pierwszym z nich jest właśnie wyidealizowany lub fantastyczny obraz jakiejś rzeczy. Zatem użyte przez Z. Kubiaka widma są jak najbardziej ekwiwalentne. Niemniej istnieje także drugie znaczenie - $i v \delta \alpha \lambda \mu \alpha$ jako przedmiot podziwu, uwielbienia, kul$\mathrm{tu}^{13}$. Mając na uwadze także to drugie znaczenie możemy dogłębniej zrozumieć, jak wielką rolę $\mathrm{w}$ życiu podmiotu lirycznego odgrywały owe widma miłosne, które urastają do roli obiektu uwielbienia i kultu.

Wróćmy jednak do interpretacji utworu. Otaczający osobę mówiącą widok zlewa się $\mathrm{w}$ jedność $\mathrm{z}$ jego wewnętrznym, emocjonalnym światem. Znamienne jest użycie nawiasu. Zawarta $\mathrm{w}$ nim treść stanowi dopowiedzenie, niemniej właśnie to dopowiedzenie wyjaśnia sytuację liryczną: (to, co przez chwile po przyjściu naprawdę widziatem). Podmiot próbuje niejako sam siebie usprawiedliwić, podkreślić, że wrażenie piękna, które opisywał w pierwszej strofie było prawdziwe, że udało mu się choć na chwilkę skupić swoją uwagę na czymś innym niż otaczające go wizje. Jednak nawet jeżeli uwierzymy w te zapewnienia i przyjmiemy, że widok naprawdę wzbudził w nim podziw, to nie da się ukryć, że ten podziw był bardzo krótkotrwały. Nieistotne czy fantazję podmiotu pobudziło padające światło, czy zmieniające się kolory, czy też ogólne wrażenie piękna. Jego wyobraźnia, tak jak w każdej innej scenerii, o czym przekonuje wtrącenie nawet tu -, zaczęła snuć fantastyczne wizje. Rozpoczął się swoisty sen na jawie, w którym morze poranne, bezchmurne niebo, świetliste lazury i żólte wybrzeże ustępują miejsca wyobrażeniom, wspomnieniom, widmom miłosnym. Nie wiemy, czy zniknęły zupełnie z pola widzenia podmiotu, czy nadal widzi je w tle swojej fantazji. Cokolwiek nie działoby się w jego wyobraźni cel popatrzenia trochę na przyrode i odwrócenia uwagi od wizji, które nawiedzają go niczym zjawy nie został osiągnięty. Po lekturze całego wiersza jasne okazuje się zagadkowe stwierdzenie pierwszej strofy, o którym wspomniałam. Niech i ja trochę popatrzę na przyrodę. Znając treść drugiej strofy bez wątpienia stwierdzimy, że podmiot nigdy nie należał do miłośników natury, niemniej postanowił spróbować kontaktu z przyrodą, w celu uwolnienia się od nurtujących go wytworów fantazji. Biorąc pod uwagę wtrącenie - nawet tu -, można by pokusić się o stwierdzenie, że nawet ta ostatnia, powszechnie skuteczna, próba odnalezienia spokoju, niestety się nie powiodła.

Właśnie ze względu na nieudaną próbę odnalezienia ukojenia, niemal wszyscy krytycy łączą ten utwór z biografią poety i uważają Morze poranne za wiersz, w którym przemawia sam Kawafis. I. M. Panagiotopoulos uważał, że wyraża on stosunek poety do natury, która zawsze była mu obca. Określa Kawa-

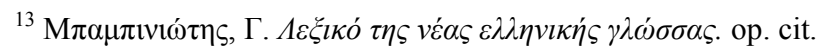

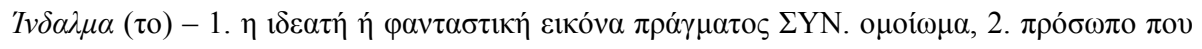

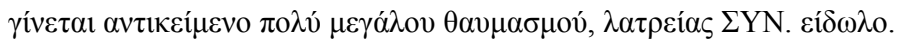


fisa jako twórcę zamkniętej przestrzeni, w której miał on najlepiej odczuwać magię swoich widm milosnych ${ }^{14}$. G. Wrisimitzakis charakteryzuje go jako twórcę miasta, poetę - urbanistę, który zmęczony jego otoczeniem i zachęcony powszechnymi przekonaniami udaje się nad brzeg morza, aby poczuć ożywczą siłę natury. Jednak nie udaje mu się uwolnić myśli dzięki widokowi morza, gdyż jako człowiek nierozerwalnie złączony z urbanistyczną kulturą nie odnajduje w naturze niczego, co chociażby w najmniejszym stopniu odzwierciedlało jego wnętrze. Zatem przyroda tylko na chwilę zajmuje jego uwagę, aby ustąpić miejsca jego erotycznym wizjom. Wrisimitzakis konsekwentnie interpretował większość Kawafisowych utworów pod kątem nieustannej próby odnalezienia wytchnienia $\mathrm{w}$ otoczeniu ${ }^{15}$. Niemal nierozerwalnie łącząc dzieło poety $\mathrm{z}$ jego osobistym życiem uważał, że chorobliwie hedonistyczny Kawafis, nękany swoimi erotycznymi wizjami próbował za wszelką cenę znaleźć od nich drogę ucieczki ${ }^{16}$.

Dla Kawafisa inspiracją był świt, natomiast Verlaine'a w wierszu Zmrok mistycznego wieczora z tomiku Poematy Saturnijskie (1866) zachwyca zmierzch. Magiczny nastrój, w jaki wprowadza światło zachodzącego słońca, sprawia, że także w wyobraźni podmiotu lirycznego u Verlaine'a krajobraz miesza się ze wspomnieniami i wytworami fantazji:

\title{
Zmrok mistycznego wieczora
}

\author{
Wspomnienie z wieczornym zmrokiem \\ Drżącymi barwy się mieni \\ Na horyzoncie z płomieni \\ Nadziei, co pod mym wzrokiem \\ Rozrasta się na kształt ściany \\ Lub na kształt dziwacznej kraty, \\ Po której się tulipany \\ I dalie, i jaskru kwiaty, \\ I lilie aromatyczne \\ Wiją w kontury mistyczne.
}

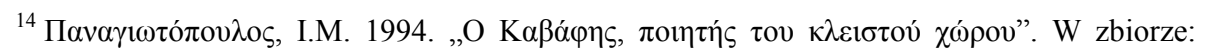

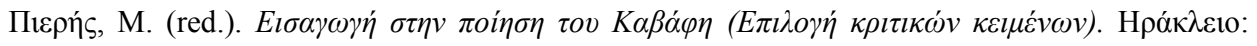

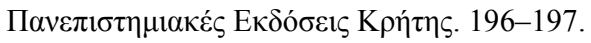

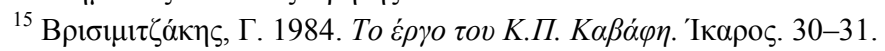

Wrisimitzakis potwierdzał swoją teorię również wierszem Wieczorem, w którym ukazana zostaje scena, w której podmiot liryczny, po oddaniu się lekturze jakiegoś listu z przeszłości, pełen melancholii wychodzi na balkon, aby popatrzeć na ukochane miasto. Krytyk interpretował tę sytuację liryczną jako metaforę poszukiwania wytchnienia w otoczeniu. Nękany wspomnieniami, które ogarnęły jego świat wewnętrzny, podmiot ucieka do rzeczywistego świata zewnętrznego.

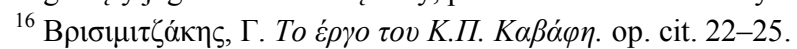




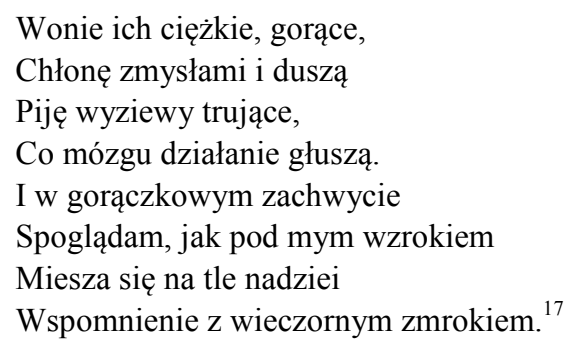

Widzimy to już $\mathrm{w}$ pierwszym wersie, w którym wspomnienie i wieczorny zmrok tworzą jedność. Warto zwrócić uwagę na to, że w oryginale ${ }^{18}$ obydwa te terminy zostały napisane dużą literą, co wyraźnie podkreśla nie tylko, jak istotną rolę pełnią w wierszu, ale zaznacza też swoisty majestat siły Wspomnienia i siły Zmierzchu. Dzięki takiemu zabiegowi zarówno wspomnienie jak i zmierzch ożywają i urastają do roli swoistych bożków, niemalże żywych postaci, które wymagają wyjątkowej czci ${ }^{19}$. Utwór niewątpliwie ma charakter mocno zabarwiony mistycyzmem, mamy wrażenie, że osoba mówiąca jest ogarnięta gorączkowym chaosem. Wiersz próbuje ukazać nam proces, w którym widziany przed oczyma podmiotu lirycznego krajobraz, zmienia się w jego wyobraźni i tworzy fantastyczne widziadła. Ta zmiana zachodzi nagle, nieświadomie i bardzo dynamicznie, a jej efekt można scharakteryzować jako irracjonalny i chaotyczny. Pomimo iż przekaz utworu sprawia takie wrażenie, w żadnym wypadku nie można tego powiedzieć o zastosowanej przez autora technice. Pozorny chaos jest bowiem niewątpliwie celowym zabiegiem, próbą oddania charakteru ludzkiej fantazji, w której nic nie musi, a wręcz nie powinno być logiczne i racjonalnie ze sobą powiązane.

Podmiot liryczny pod wrażeniem zachodzącego słońca, widzi przed sobą wspomnienia zmieszane z magią zmierzchu. Do tego momentu wszystko wydaje się logiczne i prawdopodobne. Człowiek widzi przed sobą piękny zachód słońca, który przywołuje w jego pamięci jakieś wspomnienie. Może jakiś inny zmierzch, oglądany przed laty? A może podobny pejzaż? Przemyślenia podmiotu nie zatrzymują się jednak na przywołaniu sytuacji z przeszłości. Wspomnienie i wieczorny Zmierzch mienią się bowiem drżacymi barwami na horyzoncie

\footnotetext{
${ }^{17}$ Verlaine, P. 1980. Zmrok mistycznego wieczora. Przekład Barbary Beaupre. W zbiorze: Verlaine, P. Poezje. Warszawa: Państwowy Instytut Wydawniczy. 71.

${ }^{18}<\mathrm{http} / / / \mathrm{www}$. toutelapoesie.com/poemes/verlaine/poemes_saturniens/paysages_tristes/crepu scule_du_soir_mystique.htm>, 29.09.2012.

${ }^{19}$ Tę technikę kilkakrotnie stosował także Kawafis, chociażby wyróżniając Cienie Miłości w wierszu Aby nadeszly Cienie. W Morzu porannym nie napotykamy tej techniki, niemniej warto pamiętać o znaczeniu słowa $i v \delta \alpha \lambda \mu \alpha$, które analizowałam powyżej. Zatem także w tym utworze spotykamy pewną próbę wyrażenia swoistego kultu dla niematerialnych bytów.
} 
z płomieni nadziei. W tekście oryginału mistyczny charakter został jeszcze bardziej podkreślony, wyrażeniem

czerwienieja $i$ drża na rozpalonym horyzoncie Nadziei ${ }^{20}$. Zatem do tworu wyobraźni podmiotu, w którym zmieszały się Zmierzch i Wspomnienie dołącza także Nadzieja. Zauważamy tu charakterystyczne dla Verlaine'a pojmowanie czasu. Zmierzch to element reprezentujący teraźniejszość. W tej chwili podmiot widzi go przed swoimi oczyma. Wspomnienie to z kolei punkt odniesienia do zdarzeń z przeszłości. Natomiast Nadzieja jako odczucie związane z tym, co ma dopiero nadejść, określa przyszłość. Zatem $\mathrm{z}$ racjonalnego punktu widzenia są to wartości, wzajemnie się wykluczające. Co dzieje się natomiast w sytuacji lirycznej Zmroku mistycznego wieczora? Te trzy elementy przeplatają się ze sobą $\mathrm{z}$ niewiarygodną lekkością, a w wyobraźni podmiotu tworzy się obraz wspomnień, zabarwionych obecnym wrażeniem i wizją nadchodzących losów.

To jednak wcale nie koniec widziadła. Fantazja podmiotu ciągle pracuje, a widziane przez niego obrazy ulegają nieustannym metamorfozom. Teraz wizja zmienia się niespodziewanie i rozrasta się na ksztalt ściany lub na ksztalt dziwacznej kraty, po której pną się kwiaty. Motyw kwiatów wydaje się wyjątkowo interesujący. Pomiot wylicza widziane przez siebie kwiaty - dalie, lilie, tulipany, jaskry. Z racji tego, że rośliny bardzo często pełnią rolę metafory, chciałoby się odwołać do ich symboliki, szukać $\mathrm{w}$ dalii niepewności, w lilii niewinności, $\mathrm{w}$ tulipanie radości a $\mathrm{w}$ jaskrze gniewu ${ }^{21}$. Użycie utartego symbolu dla symbolisty Verlaine'a byłoby jednak nie do przyjęcia. Stanowiłoby o zbyt dosłownym wyrażeniu treści. Symboliści natomiast wielokrotnie podkreślali, że symbol w przeciwieństwie do alegorii jest jednostkowym odpowiednikiem wyrażanej idei. Według symbolistów prawdziwy sens istnienia zawiera się w idealnym, niepoznawalnym przez ludzki rozum świecie, skrytym pod ułudną zasłoną świata materialnego. Według Stephane'a Mallarme'ego świat jest rzeczywistościa fikcyjna, żyjaca $w$ duszy poety ${ }^{22}$. Tylko „twórca - jasnowidz” ma świadomość istnienia świata idei, natomiast literatura, a przede wszystkim poezja ma za zadanie wyrazić tę skrytą sferę, musi jakoś zasugerować jej istnienie. I właśnie w tej funkcji wspaniale sprawdza się symbol, będący jednocześnie odpowiednikiem idei i opisem stanu ludzkiej duszy. Właśnie dlatego, że jest jednocześnie wyrażeniem stanu duszy artysty, charakteryzuje się silną wieloznacznością, niedopowiedzeniem i tajemnicą, co z kolei umożliwia różnorodne interpretacje.

\footnotetext{
${ }^{20}$ Tłumaczenie filologiczne zaczerpnięte z: Żurowski, M. 1980. „Wstęp”. W zbiorze: Verlaine, P. Poezje. op. cit. 45.

${ }^{21}<$ http://www.asflor.pl/mowa.htm>, 28.09.2012. Por. Kopaliński, W. 2007. Słownik symboli. Warszawa: HPS.

${ }^{22}$ Sadkowska, A. Synteza sztuk we francuskim romantyzmie $i$ symbolizmie. $<$ http://biesiada. polon.uw.edu.pl/symbolizm.htm>, 22.09.2012.
} 
Prymat sugestii i niedopowiedzenia wyrastał z przekonania, że zwyczajne podanie nazwy danej rzeczy odbiera czytelnikowi trzy czwarte przyjemności estetycznej ${ }^{23}$. A przecież to właśnie estetyzm miał być jednym z głównych wyznaczników „sztuki dla sztuki”. Mając świadomość tych założeń symbolizmu, nie powinien dziwić fakt, że Ph. Stephan przestrzega przed odwoływaniem się do powszechnej symboliki twierdząc, że kwiaty u Verlaine'a niekoniecznie funkcjonują jako symbole. Zaznacza przy tym, że często są aluzją do nastroju, który odczuwa podmiot ${ }^{24}$. Zatem, biorąc pod uwagę różnorodność przytaczanych kwiatów, wyraźnie widać nagromadzenie emocji. Kwiaty i ich wyziewy upajają podmiot, a więc to raczej nastrój, jaki wywołał u niego Zmierzch w połączeniu ze Wspomnieniem i Nadzieja przyprawił go o ten stan upojenia. Zewnętrzny, rzeczywisty obraz staje się bodźcem pobudzającym wewnętrzny, emocjonalny świat podmiotu. Wizja Wspomnienia zmieszanego ze Zmrokiem i Nadzieją, zamienia się w wizję wyrażającą przeróżne, chwilami nawet sprzeczne uczucia, które upajają osobę mówiącą w wierszu. Ich wyziewy to trucizna, która pochłania zmysły, duszę i myśli. Warto zwrócić uwagę na określenia użyte w oryginale - 'gorące i ciężkie perfumy, których trucizna sprawia, że toną moje zmysły, moja dusza, mój rozum, ${ }^{25}$. Zatem użyty w polskim tłumaczeniu ekwiwalent wyziewy wydaje się nie być zbyt odpowiednim, z racji tego, że nadaje zapachowi kwiatów pewne pejoratywne nacechowanie. Tymczasem francuskie parfums oznaczają po prostu woń czy zapach, ale nawet perfumy. Mając na uwadze to ostatnie znaczenie, odbieramy ten wers w zupełnie inny sposób, powiem woń kwiatów staje się dla podmiotu wspaniałym doznaniem. Zapach upaja nie tylko ze względu na to, że jest silny i przytłaczający, ale przede wszystkim dlatego, że jest piękny. Te nadzwyczaj przyjemne, ciężkie i gorace wonie powoduja goraczkowy zachwyt, a zgodnie $\mathrm{z}$ oryginałem bezgraniczne omdlenie $^{26}$, którym upajają. Podmiot $\mathrm{w}$ żadnym stopniu nie kontroluje już swojej fantazji. Mamy wręcz wrażenie, że ta od pewnego momentu galopuje jak szalo-

\footnotetext{
${ }^{23}$ Patrz przypis 21.

${ }^{24}$ Stephan, Ph. Paul Verlaine and the decadence 1882-1890. <http://books.google.gr/books ?id=hRoNAQAAIAAJ\&pg=PA124\&lpg=PA124\&dq=verlaine's+article+on+baudelaire \&source= bl\&ots=-6nr0yuvex\&sig=uqDEji01Sk6hC2i4fcn0B6tWJKs\&hl=pl\&ei=2gDVTp61IeXO4QSZx8

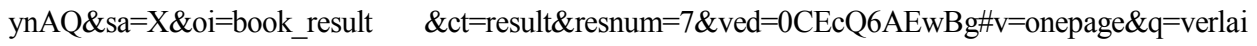
ne's\%20article\%20on\%20baudelaire\&f=false>, s. 103, 29.09. 2012.

${ }^{25}<\mathrm{http}$ ///www.toutelapoesie.com/poemes/verlaine/poemes_saturniens/paysages_tristes/crepu scule_du_soir_mystique.htm $>, 29.09 .2012$

De parfums lourds et chaouds, dont le poison

Noyant mes sens, mon ame et ma raison

${ }^{26}<\mathrm{http}$ //www.toutelapoesie.com/poemes/verlaine/poemes_saturniens/paysages_tristes/crepu scule_du_soir_mystique.htm>, 29.09.2012

une immense pamoison
} 
na i przytłacza osobę mówiącą w wierszu. Podmiot nie może jej w żaden sposób okiełznać, opanować, zahamować. Nie ma świadomości, co się z nim dzieje, jest odurzony irracjonalnymi wizjami, które ogarniają go niczym demony. Nagle, zupełnie niespodziewanie, szalone widziadła znowu wracają do formy, w której Wspomnienie miesza się ze Zmierzchem. Mamy wrażenie, że pod wpływem krajobrazu podmiot daje ponieść się fantastycznym wizjom i udaje się wraz z nimi w krótką podróż po niezgłębionych, irracjonalnych zakątkach swojej wyobraźni, po czym powoli powraca do rzeczywistości, w której oglądany zmierzch przywołuje mu na myśl jakieś wspomnienie z przeszłości.

Dynamika zmian obrazu poetyckiego w Zmroku mistycznego wieczora wydawała się niewyobrażalna pierwszym krytykom Verlaine'a, których niewątpliwie zaskakiwało jego nowatorstwo. Pozwolę sobie przytoczyć rozważania J. Lemaitre'a na temat tego właśnie wiersza, pochodzące z artykułu z 1888 roku: Czy rozumiecie? Można pojąć, że istnieje zwiąek, podobieństwo między wspomnieniem i zmierzchem, melancholia zachodu stońca, dnia, który umiera, i smutkiem odczuwanym, kiedy się wspomina umarła przeszłość. Ale między zmierzchem i nadzieja? Jak umyst poety przechodzi od jednego do drugiego? Zmierzch niewatpliwie może wyobrażać wspomnienie, dlatego, że też jest smutny, i może (nie bez trudności) wyobrażać również nadzieje, skoro mu zostało trochę światła, czasem petnego blasku i uroku, ale jak może wyobrażać zarazem jedno $i$ drugie? A ,wspomnienie ze zmierzchem czerwieniejace na horyzoncie nadziei”, cóż to znaczy wielcy bogowie? „Niezdrowy wyziew zapachów ciężkich” (zapachy dalii i tulipana?), to powiedzmy, wspomnienie, lecz „,bezgraniczne omdlenie" raczej oznaczałoby nadzieję.. Gtowa pęka!. Po czym dodaje, że Jest to niemal poezja przed słowem, poezja limbów, marzenia zapisanego ${ }^{27}$. Zakłopotanie Lemaitre'a wynikało z faktu, że do tej pory nikt nie odważył się tworzyć w ten sposób. Niewątpliwie trudno było krytykom pogodzić się z próbą oddania w poezji niezgłębionych tajemnic ludzkiego wnętrza. Verlaine'owi jednak nie wystarczyłby pejzaż, przywołujący $\mathrm{w}$ pamięci jakieś zdarzenie $\mathrm{z}$ przeszłości. Poeta budował swoje wiersze na podstawie obrazów lub refleksji, które odzwierciedlają zmienne impresje podmiotu lirycznego. Kompozycja wielokrotnie jest luźna, czytelnik ma wrażenie, że refleksje swobodnie, a jednocześnie w niespodziewanym rytmie, wypływają z głębi duszy. Verlaine jako symbolista musiał wyrazić to, co niewyrażalne, musiał sięgnąć po tak trafnie określoną przez Lemaitre'a poezję przed słowem.

Pomimo iż Kawafisowego Morza porannego na pewno nie można by określić słowami wypowiedzi Lemaitre'a, to jednak pomiędzy nim a Zmrokiem mistycznego wieczora Verlaine'a widać wyraźną analogię. Podmioty liryczne w obydwu utworach patrzą na grę światła słonecznego i zmiany obrazu natury,

${ }^{27}$ Żurowski, M. 1980. „Wstęp”. W zbiorze: Verlaine, P. Poezje. op. cit. 45-46. 
które jednak nie stanowią dla nich absolutnego piękna samego w sobie, a urastają do roli bodźca, dzięki któremu przeżywają swoje osobiste emocje. W centrum uwagi niewątpliwie pozostaje sam człowiek, jego przemyślenia, odczucia, wyobrażenia, magia jego wewnętrznego świata. Pozwolę sobie na stwierdzenie, że obydwa utwory wzajemnie się uzupełniają. Gdybyśmy nie zwracali uwagi na porę dnia i wstawili treść Verlaine'owskiego wiersza pomiędzy strofy Morza porannego Kawafisa, uzyskalibyśmy pełny opis przedstawianego przez obydwu autorów procesu. Początkowo następowałby pierwszy kontakt z krajobrazem, czyli chwila, w której, jak zapewniał Kawafis, człowiek naprawdę widzi tylko naturę. Na tym etapie całkowicie racjonalnie odbiera rzeczywistość i jest w pełni świadomy piękna otaczającego go krajobrazu. Następnie piękny widok wzbudzałby u niego jakieś wrażenie, przypominałby jakieś zdarzenie, po czym, jak to ujął Verlaine, człowiek traciłby świadomość rzeczywistości, pozwalając swoim myślom na dynamiczny i absolutnie niekontrolowany pęd po najciemniejszych zakamarkach swojego wewnętrznego świata. Natomiast w momencie, gdy otrząsnąłby się ze swojego snu na jawie, tak jak podmiot u Kawafisa, doszedłby do wniosku, że jakkolwiek piękna nie byłaby ta natura, to nie jest ona $\mathrm{w}$ stanie przykuć na dłużej jego uwagi, a przede wszystkim nie pozwala mu pohamować nękających go wrażeń i wytworów fantazji. Tą hipotetyczną syntezą obydwu utworów chciałam podkreślić fakt, że pomimo iż obydwa wiersze należą do liryki bezpośredniej i w gruncie rzeczy opisują podobne zdarzenie, to każdy $\mathrm{z}$ autorów przedstawił ten analogiczny proces $\mathrm{z}$ innego punktu widzenia. Kawafis podsumował to, co zdarzyło się przed i po nawiedzających jego podmiot wizjach. Przerwa pomiędzy strofami Morza porannego jest właśnie tą chwilą, w której do głosu dochodzi niczym niepohamowana fantazja. Natomiast Verlaine zbudował swój utwór wokół piętrzących się wyobrażeń. Dlatego też tak widoczna jest różnica nastroju w obydwu wierszach. U Kawafisa króluje statyka i opanowanie, podczas gdy Verlaine'owski Zmierzch mistycznego wieczora uderza dynamiką i gorączkowym szałem. Bardzo istotne zadanie spełnia tu także budowa stroficzna utworów. Kawafis podziałem na strofy wyraźnie zaznaczył odstęp czasowy pomiędzy przedstawianymi sytuacjami. Z kolei Verlaine rezygnując $\mathrm{z}$ wiersza stroficznego, zadbał o nieprzerwany bieg nakładających się na siebie wizji.

Niewątpliwie fakt, że każdy z poetów przedstawił inną płaszczyznę tego samego procesu, wynika z różnych głównych założeń, które przyjmowali ci twórcy. Wspomniałam o wielości prądów istniejących na przełomie XIX i XX wie$\mathrm{ku}$. Impresjonizm, dekadentyzm, symbolizm, estetyzm, ekspresjonizm, futuryzm oraz inne tendencje pozwalały twórcom tamtego okresu wybrać pasujące do nich założenia i wypracować sobie własny, idealnie odzwierciedlający swój twórczy zamysł, poetycki wyraz. Dlatego też realista Kawafis przedstawił nam podmiot liryczny świadomy stanów, które przeżywa. Sytuacja liryczna, w której go poznajemy jest całkowicie realistyczna i trwa w swoim realizmie przez cały utwór. 
Z takim samym opanowaniem podmiot mówi o pięknie morza, na które patrzy i o świadomości, że jednak nie udało mu się oderwać od nękających go widm. U impresjonisty Verlaine'a nie uda nam się odnaleźć świadomości. Osoba mówiąca w Zmierzchu mistycznego wieczora nie panuje nad szalonym biegiem swojej fantazji. Nie znaczy to jednak, że początkowo podmiot Verlaine'a nie widział rzeczywistego obrazu ukazującej się przed nim przyrody. Nie znaczy to również, że w chwili, gdy otrząsnął się z chaosu tworów swojej wyobraźni, nie był świadomy fantastycznej podróży, którą przed chwilą odbył. Analogicznie, osoba mówiąca w Morzu porannym w momencie, gdy ogarniały ją widma milosne z pewnością nie była w stanie zachować swojego opanowania i świadomości tego, co się $\mathrm{z}$ nią dzieje. Gdyby tak było, w wierszu nie znalazłyby się wersy I niech się tudze, że to ogladam (to, co przez chwile po przyjśsiu naprawdę widziatem). W gruncie rzeczy, podmioty liryczne obydwu utworów różni zaprawdę niewiele. Ogromną różnicą jest jednak spojrzenie Kawafisa i Verlaine'a na daną sytuację liryczną, które wyraźnie wynika z obranej przez każdego z twórców drogi poetyckiej.

Kawafis w swojej dojrzałej twórczości zdecydowanie skłonił się ku realizmowi. Założenia tego prądu umożliwiły mu szczegółowe przekazanie istoty swojego natchnienia. Ścisłe i obiektywne odwzorowanie rzeczywistości pozwoliło mu na wypracowanie stylu, w którym emocjonalność wypływa z pozornie neutralnych obrazów codzienności, a nie z wybujałych środków stylistycznych. Twórczość Kawafisa jest bez wątpienia przepełniona realizmem, ale jednocześnie nie jest to realizm całkowicie pozbawiony liryzmu. Zgodnie z przekonaniem D. Nikolareizisa poezja Kawafisa utrzymuje równowage pomiędzy zgłębianiem subiektywnych wrażeń $i$ realizmem ${ }^{28}$. Z pozornie suchych i obojętnych wersów prezentujących pewien element rzeczywistości, tak jak krajobraz w interpretowanym wyżej wierszu, samoistnie wypływają wspomnienia, odczucia, wrażenia, których w przekonaniu poety nie trzeba już bliżej określać. Kawafis wbrew ideałom królującym w ówczesnej greckiej poezji, zwrócił się ku codziennemu życiu i wewnętrznej naturze człowieka. Starał się odtworzyć ludzką codzienność bez zbędnego upiększania jej stylistycznymi środkami wyrazu, tak jakby sądził, że każdy z nas dzięki swoim odczuciom nadaje jej osobisty emocjonalny charakter. Realizm Kawafisa wynika z głębokiej znajomości współczesnego mu świata, którą w swoim dziele ubarwiał w najróżniejsze tła. Owszem, $\mathrm{z}$ reguły są to scenerie miejskie lub pseudohistoryczne ${ }^{29}$, jednakże taką rolę mo-

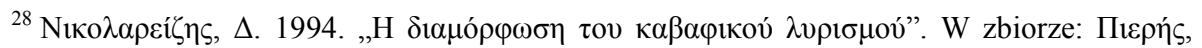

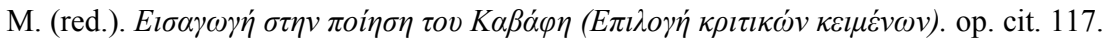

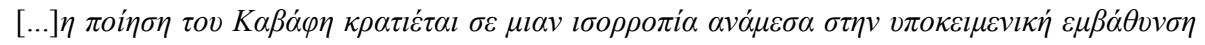
$\tau \omega \nu \varepsilon v \tau v \pi \omega ́ \sigma \varepsilon \omega v \kappa \alpha l \sigma \tau o v \rho \varepsilon \alpha \lambda l \sigma \mu o ́$.

${ }^{29}$ Określenie używane przez krytyków Kawafisa w kontekście postaci fikcyjnych, które są bardzo konkretnie opisywane w utworach o tematyce historycznej, tak, że czytelnik ma wrażenie 
że pełnić także pejzaż. Pomimo iż obrazy zawarte $\mathrm{w}$ wierszach są $\mathrm{w}$ mniejszym lub większym stopniu wytworem fantazji poety, czytelnik ma wrażenie, że tworzą one elementy rzeczywistości. Każdy z nas bez większego problemu może przecież przywołać w myślach widok wschodu słońca nad morzem. Poeta przeskakuje z prawdopodobnego $w$ prawdopodobne $e^{30}$ budując przekonanie, że utwory są relacją $\mathrm{z}$ tego, co albo się zdarzyło, albo przynajmniej miało pełne prawo się kiedyś zdarzyć. Zwięzłe, a jednocześnie dokładne, obrazy Kawafisa sprawiają wrażenie bliższych umysłowi niż uczuciom. Nie bez znaczenia w nich jest również prawie całkowity brak środków stylistycznych, który wyklucza podniosłe stylizowanie przedstawianych scen. T. Malanos wyraźnie podkreślał, że Kawafis porzucał elementy poetyckie, aby móc wierniej oddać dane wydarzenie, aby móc przedstawić rzeczywistość w sposób, w jaki widzą ją inni. Twierdził, że Kawafis nie oddala się nigdy od rzeczywistości. Z niej wyrusza i do niej powra$c a^{31}$. Związek twórczości poety z rzeczywistością zaznaczali również inni krytycy, jak na przykład D. Nikolareizis, mówiąc, że jego poezja jest zbudowana na zdarzeniach, które przyniosło mu życie, jest złaczona z rzeczywistościa ${ }^{32}$. Nic zatem dziwnego w fakcie, że Kawafis przedstawił w Morzu porannym okoliczności tworzenia się fantastycznych wizji, a nie sam ich proces. Tylko w ten sposób mógł bowiem przedstawić fantastyczne widma miłosne nie rezygnując $\mathrm{z}$ realizmu.

Zgoła inaczej wygląda to w przypadku Verlaine'a zainspirowanego symbolizmem i mglistym impresjonizmem. Dla tego poety idealną sytuacją liryczną były właśnie zawiłe wędrówki ludzkiej wyobraźni. Verlaine w swojej poezji kładł nacisk przede wszystkim na opis samego ulotnego wrażenia. W dojrzałym okresie twórczym bez wątpienia przeważa impresja, melancholia, subiektywne spojrzenie na otaczającą rzeczywistość. Według tego twórcy to nie opis postaci czy konkretnego wydarzenia pozwala ukazać prawdziwy charakter liryki, ale właśnie próba uchwycenia chwilowego odczucia. Rzeczy materialne zmieniają swój charakter i stają się niematerialnymi wrażeniami. Obiektywna prawda

jakby faktycznie były postaciami historycznymi. Np.: Eumenes w wierszu Pierwszy stopień czy Kimos w utworze Na italskim wybrzeżu.

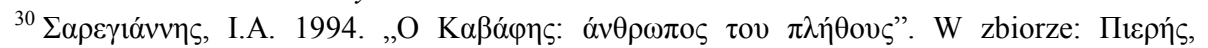

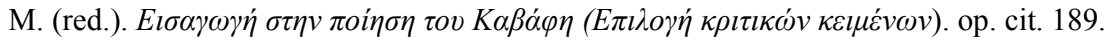

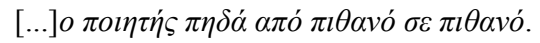

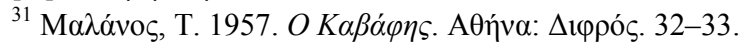

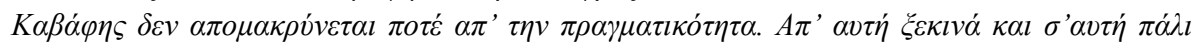
$\varepsilon \pi \iota \sigma \tau \rho \varepsilon ́ \varphi \varepsilon l$.

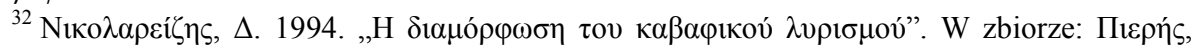

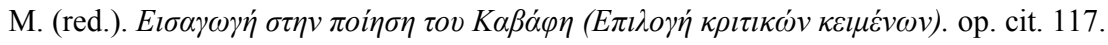

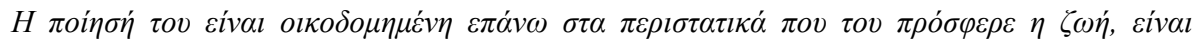
$\delta \varepsilon \mu \varepsilon \dot{v \eta} \mu \varepsilon \tau \eta v \pi \rho \alpha \gamma \mu \alpha \tau \iota \kappa o ́ \tau \eta \tau \alpha$. 
o świecie nie istnieje, zatem aby go poznać należy zwrócić uwagę na subiektywne, przypadkowe impresje, które budzą się, aby za chwilę, w mgnieniu oka nieodwracalnie zniknąć. Wszystkie te przekonania wyraźnie widać w dynamicznych metamorfozach Zmierzchu mistycznego wieczora. Verlaine'owska kompozycja wielokrotnie jest luźna, co sprawia u czytelnika wrażenie pewnego nieładu i braku logiki. Ta technika może dać błędne wrażenie bezsensu i niejasności, niemniej stanowi najodpowiedniejszy sposób wyrażenia świata wewnętrznego, który jest właściwie niewyrażalny. Krytycy twierdzą, że można w jego twórczości wyróżnić dwa typy impresjonizmu jeden migawkowy, bardziej nowoczesny dzięki dynamizmowi fragmentarycznych obrazów, $i$ drugi - statyczny, bardziej po malarsku operujący kolorem i płynnościa konturów ${ }^{33}$. Niewątpliwie w przypadku Zmierzchu mistycznego wieczora należałoby mówić o dynamicznym impresjonizmie migawkowym. Po pierwsze świadczy o tym nagromadzenie obrazów, które przenikają się wzajemnie, aby niemal natychmiast ustąpić miejsca kolejnym. Wieczorny zmrok łączy się z Wspomnieniem, potem nagle pojawia się Nadzieja. Jednocześnie horyzont z płomieni [...] rozrasta się na ksztalt ściany, po czym natychmiast owa ściana przemienia się w dziwaczna kratę, na której zaczynają wić się przeróżne kwiaty. O dynamice utworu świadczy także niespodziewane przerzucenie głównej osi wiersza z zewnętrznego krajobrazu na skutki, które widziane obrazy wywołały w wewnętrznym świecie podmiotu, aby w końcowych wersach znowu wrócić do wspomnienia i obrazu przyrody. Warto zwrócić uwagę na pierwszy i ostatni wers. Są one identyczne - Wspomnienie $z$ wieczornym zmrokiem. Co więcej, $\mathrm{w}$ tekście oryginalnym ${ }^{34}$ widnieje jeszcze jedno powtórzenie. Wers szósty i dziesiąty także są takie same - dalia, lilia, tulipan i jaskier. Bogactwo rytmicznych środków stylistycznych, chociażby po-

${ }^{33}$ Żurowski, M. 1980. „Wstęp”. op. cit. 47.

${ }^{34}<$ http://www.toutelapoesie.com/poemes/verlaine/poemes_saturniens/paysages_tristes/crepu scule_du_soir_mystique.ht, $>, 13.10 .2012$

Le Souvenir avec le Crépuscule

Rougeoie et tremble à l'ardent horizon

De l'Espérance flamme qui recule

Et s'agrandit enainsi qu'une cloison

Mystérieuse où mainte floraison

- Dahlia, lys, tulipe et renoncule -

S'élance autour d'un treillis, et circule

Parmi la maladive exhalaison

De parfums lourds et chauds, dont le poison

- Dahlia, lys, tulipe et renoncule -

Noyant mes sens, mon âme et ma raison,

Mêle dans une immense pâmoison

Le Souvenir avec le Crépuscule. 
wtórzenie wyliczenia, o którym właśnie wspomniałam, w połączeniu z nagromadzeniem czasowników wprowadza nas, dzięki silnemu elementowi muzyczności, w nastrój szalonego pędu. Zatem nie tylko treść, ale także budowa wiersza wyraźnie sugerują „migawkową” podróż po zakamarkach wyobraźni, z której podmiot wraca dokładnie tą samą drogą w to samo miejsce, z którego wyruszył. Dla impresjonisty, którym bez wątpienia był Verlaine, nie istotne było to, co działo się z podmiotem lirycznym przed i po szalonej podróży. Jego zadanie stanowiło ukazanie tego, co niewyrażalne, tego, czego normalny obserwator nie potrafiłby dostrzec w danej sytuacji.

Jakkolwiek różne nie byłyby wykorzystywane przez Kawafisa i Verlaine'a techniki, a nawet sam pryzmat, przez który widzą przedstawiany w swoich utworach proces, to pewne elementy funkcjonują analogicznie. Przede wszystkim mam na myśli rolę, jaką w obydwu wiersza pełni obraz natury. Krajobraz zostaje ubarwiony subiektywnymi emocjami, staje się bodźcem do stworzenia fantastycznych wizji, po czym przesuwa się do roli tła, a może nawet zupełnie znika ze świadomości podmiotu, aby ustąpić miejsca temu, co w modernizmie najważniejsze - czyli ludzkim odczuciom. Obydwa utwory są świadectwem jeszcze jednego założenia modernizmu, można je bowiem określić jako lirykę nieosobową. Pomimo iż na podstawie lektury wiersza możemy dokładnie odtworzyć w myślach sytuację liryczną, to gdy przyjrzymy się bliżej elementom zawartym w utworze, zauważamy, że w zasadzie nie ma w nim prawie żadnych szczegółów. Wykorzystywane obrazy są tak silnie niekreślone, że pobudzają nas do tego, abyśmy sami dopowiedzieli sobie wszelkie konkretne informacje. Prześledźmy to na przykładzie Morza porannego. Wspomniałam o użytych przez Kawafisa przymiotnikach, których poeta z reguły unikał. Zauważmy jednak, że są to epitety bardzo ogólne. Czy określenie świetliste lazury czy żólte wybrzeże wyraża jakąkolwiek nietypowość opisywanego krajobrazu? Lazury są świetliste bowiem padają na nie promienie wschodzącego słońca. Żółte wybrzeże także jest zjawiskiem powszechnym. Mamy więc do czynienia z realistycznym opisem, a nie chęcią zaprezentowania wyjątkowego krajobrazu. Zwróćmy uwagę także na epitety wartościujące, które z założenia powinny ukazywać subiektywne i niepowtarzalne wrażenia podmiotu. Jednak tu także znajdujemy bardzo ogólnikowe wyrażenia: wszystko piękne i ogromne. Nawet opatrzone przymiotnikami elementy krajobrazu nie są szczegółowo określone, a co dopiero w przypadku wyliczenia moje wyobrażenia, wspomnienia, widma miłosne. Zastanówmy się nad tym, czy wiemy z treści wiersza, jaki był ich charakter. Niewątpliwie nie wiemy, ale tak samo niewątpliwie każdy z nas bezwiednie odczytał sens tego wyliczenia poprzez pryzmat swoich wyobrażeń, wspomnień $i$ widm mitosnych. Analogicznie wygląda to w przypadku Wspomnienia i Nadziei w Verlaine'owskim Zmierzchu mistycznego wieczora. Dzięki głębokiej nieokreśloności i niedomówieniom, każdy z czytelników może bez trudu utożsamić się z pod- 
miotami lirycznymi, a co więcej, bardzo prawdopodobne jest to, że wcieli się w rolę osoby mówiącej w wierszu, nie mając tego świadomości. Obydwaj poeci dzięki temu, że nie nazwali i nie określili jednoznacznie towarzyszących swoim podmiotom wrażeń, zdołali stworzyć ponadczasowe utwory, w których każdy czytelnik może odnaleźć cząstkę siebie. Uważam, że obydwa wiersze idealnie odzwierciedlają słowa Oscara Wilde'a, według którego ludzie znajduja w naturze to, co sami do niej wnosza ${ }^{35}$, ponieważ zarówno Morze poranne jak i Zmierzch mistycznego wieczora nie tylko prezentują nam pogląd Kawafisa i Verlaine'a na naturę, ale poprzez swój nieosobowy charakter pozwalają nam w swoich obrazach odnaleźć to, co każdy z nas czytelników sam do niej wnosi.

\section{Bibliografia}

\section{Teksty źródłowe}

Kawafis, K. 1981. Wiersze zebrane. Przekład Zygmunta Kubiaka. Warszawa: Państwowy Instytut Wydawniczy.

Verlaine, P. 1980. Poezje. Warszawa: Państwowy Instytut Wydawniczy.

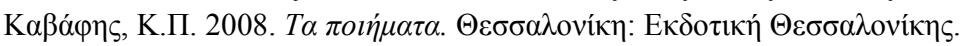

\section{Opracowania}

D’ Eaubonne, F. 1963. Niepokój życie Verlaine'a. Warszawa: Czytelnik.

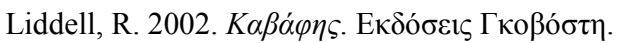

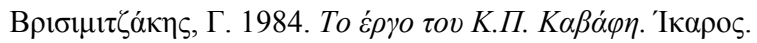

I

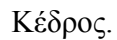

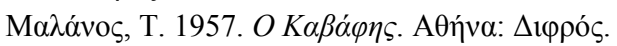

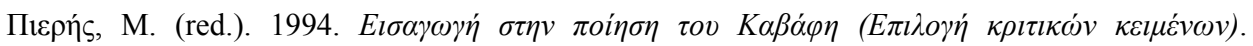

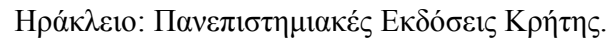

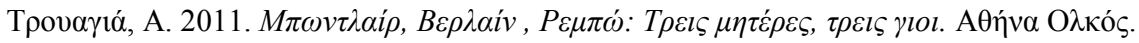

\section{Słowniki}

Abramowiczówna, Z. 1960. Stownik grecko - polski. Tom II. Warszawa: PWN.

Kopaliński, W. 2007. Słownik symboli. Warszawa: HPS.

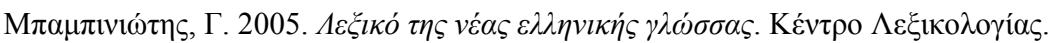

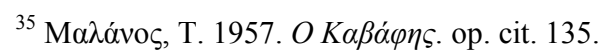




\section{Źródla internetowe}

Symbolika kwiatów: < http://www.asflor.pl/mowa.htm>.

Sadkowska, A. Synteza sztuk we francuskim romantyzmie i symbolizmie: <http://biesiada.polon. uw.edu.pl/symbolizm.htm>.

Stephan, Ph. Paul Verlaine and the decadence 1882-1890: < http://books.google.gr/books ?id=hRoNAQAAIAAJ\&pg=PA124\&lpg=PA124\&dq=verlaine's+article+on+baudelaire \&s ource=bl\&ots=-6nr0yuvex\&sig=uqDEji01Sk6hC2i4fen0B6tWJKs\&hl=pl\&ei=2gDVTp61IeX O4QSZx8ynAQ\&sa $=X \&$ oi $=$ book_result\&ct $=$ result\&resnum $=7 \& v e d=0 C E c Q 6 A E w B g \# v=$ on epage \&q=verlaine's\%20article $\% 20 \mathrm{on} \% 20$ baudelaire $\& \mathrm{f}=$ false $>$.

Verlaine, P., Crepuscule du soir mystique: <http://www.toutelapoesie.com/poemes/verlaine/ poemes_saturniens/paysages_tristes/crepuscule_du_soir_mystique.htm>. 